\title{
The effects of source and concentration of dietary fiber, starch, and fatty acids on the daily patterns of feed intake, rumination, and rumen $\mathrm{pH}$ in dairy cows
}

\author{
I. J. Salfer, ${ }^{*}$ M. C. Morelli, ${ }^{* 1}$ Y. Ying, ${ }^{* 2}$ M. S. Allen, $†$ and K. J. Harvatine ${ }^{* 3}$ \\ *Department of Animal Science, Penn State University, University Park 16802 \\ †Department of Animal Science, Michigan State University, East Lansing 48824-1225
}

\begin{abstract}
The daily patterns of feed intake and rumination influence rumen fermentation, rumen $\mathrm{pH}$, and timing of absorbed nutrients in the dairy cow, but the effects of diet composition on these patterns are not well characterized. Data from 3 previously published experiments were examined to determine the influence of dietary starch, fiber, and fatty acids (FA) on daily patterns of intake, rumination, and rumen pH. Dietary neutral detergent fiber (NDF) and starch were investigated in 2 experiments, each with duplicated $4 \times 4$ Latin square designs with a $2 \times 2$ factorial arrangement of treatments in cows fed cows $1 \times / \mathrm{d}$ at 1200 and 1400 $\mathrm{h}$, respectively. To investigate fiber content and digestibility in the first experiment, brown midrib or isogenic conventional corn silage were fed in low- and high-NDF diets (29 and 38\%, respectively). To investigate starch source and concentration in the second experiment, ground high-moisture corn or dry ground corn were fed in low- and high-starch diets (21 and 32\%, respectively). Effect of fat concentration and saturation was investigated in the third experiment using a replicated $4 \times 4$ Latin square design that fed cows $1 \times / \mathrm{d}$ at 0900 $\mathrm{h}$; treatments included a control diet with no added fat and $2.5 \%$ added saturated FA, unsaturated FA, or a mixture of the saturated and unsaturated FA. In the first 2 experiments, intake followed a similar daily pattern regardless of starch and NDF concentration or digestibility. Rumination displayed a treatment by time interaction for both NDF and starch concentration, with high-fiber, low-starch diets causing greater

Received May 15, 2018.

Accepted August 19, 2018.

${ }^{1}$ Current address: Texas A\&M College of Veterinary Medicine \& Biomedical Sciences, College Station 77845.

${ }^{2}$ Current address: Department of Medicine, Penn Center for Pulmonary Biology, Penn Cardiovascular Institute, University of Pennsylvania, Philadelphia 19104.

${ }^{3}$ Corresponding author: kjh182@psu.edu
\end{abstract}

rumination overnight but not midday. High-starch diets decreased total daily rumen $\mathrm{pH}$ equally across the day, but did not change the daily pattern. Type of corn silage did not affect the daily patterns of rumination or rumen $\mathrm{pH}$, but $\mathrm{pH}$ was reduced throughout the day in brown midrib diets. In the third experiment, no interactions between fatty acid supplement and time of day were observed for intake, rumination, or rumen $\mathrm{pH}$. Within all experiments, rumination fit or tended to fit a 24-h rhythm regardless of diet, with the amplitude of the rumination being reduced in low-starch diets and diets containing saturated FA or a mixture of saturated and unsaturated FA. Overall, intake, rumination, and rumen $\mathrm{pH}$ follow a daily pattern that was minimally modified by dietary fiber and starch type and level or fat level and fatty acid profile.

Key words: diurnal pattern, rumination, feed intake, circadian rhythm

\section{INTRODUCTION}

Circadian rhythms are endogenously generated 24-h cycles that are entrained by environmental factors including light/dark schedules and feeding time. Many physiological and behavioral processes, including hunger and satiety, are regulated by circadian rhythms, as they allow coordination of physiology and metabolism with the external environment. Dairy cows express daily patterns of feed intake and rumination (Niu et al., 2014). Cows in freestall barns eat the majority of their feed between dawn and dusk, with rapid intake immediately after feed delivery and return from the milking parlor and an increase in intake during the afternoon (DeVries et al., 2003). This diurnal pattern of intake causes daily variation in the amount of fermentable nutrients entering the rumen, modifying rumen fermentation and nutrient absorption across the day. Rumination appears to be under circadian control, exhibiting 24-h rhythms even when animals are held in constant lighting conditions (Gordon and McAllister, 1970). The rhythm of rumination is partly dependent on the 
timing of feed intake, as rumination and feeding are mutually exclusive activities, and rumination is lower during high-intake periods of the day (Murphy et al., 1983). Rumen $\mathrm{pH}$ depends on the rates of VFA production and absorption, and buffering by saliva and rumen digesta. The relationship between the external drivers of feed intake and the intrinsic rhythm of rumination may affect the digestion of feeds and rumen buffering. Most experiments show that rumen $\mathrm{pH}$ reaches a nadir approximately 7 to $9 \mathrm{~h}$ after feed delivery in cows fed a TMR once or twice per day, but the pattern varies among experiments (Dado and Allen, 1993; Nikkhah et al., 2011; Antanaitis et al., 2016).

The daily pattern of rumination has become especially relevant with the increased interest in rumination time as a prognostic tool for dairy farm management. Several correlative studies have found relationships between rumination activity and many health-related outcomes. Soriani et al. (2013) suggested that rumination time might be indicative of heat stress and decreases in response to high temperature-humidity index. Other research has suggested that decreased rumination in the peripartum period is associated with greater postpartum inflammation and incidence of clinical diseases during early lactation (Soriani et al., 2013). Furthermore, rumination time has been correlated with estrus activity (Reith and Hoy, 2012) and parturition (Büchel and Sundrum, 2014). Total daily rumination time has been reported in many experiments, but understanding the effect of diet on the daily pattern of rumination is expected to increase the utility of rumination as a diagnostic tool.

The nutrient content and physical form of diets have substantial effects on daily DMI, time spent ruminating, and rumen $\mathrm{pH}$. Increased forage fiber content increases physical fill of the rumen, causing greater satiety (Allen, 1996). High levels of starch may also cause longterm reductions in intake from greater satiety signaling via the hepatic vagus nerve (Allen et al., 2009). High concentrations of physically effective fiber increase rumination and salivation, thus increasing rumen $\mathrm{pH}$ (Beauchemin and Yang, 2005). Supplemented fat and fatty acids generally decrease feed intake, presumably from their greater energy density or stimulation of gut peptide release (Rabiee et al., 2012).

Whereas experiments examining the effect of diet composition on daily DMI, rumination, and $\mathrm{pH}$ have been conducted, little work has been done characterizing the effect of diet composition on their daily patterns. Our objective was to determine the effect of fiber, starch, or supplemented fatty acid concentration and form on the daily pattern of intake, rumination, and rumen $\mathrm{pH}$ using data from 3 previously published experiments. Our hypothesis was that the daily patterns of these responses are modified by diet composition due to differences in satiety signaling, gut fill, and rumen fermentation across the day.

\section{MATERIALS AND METHODS}

Raw feeding and ruminating behavior and rumen $\mathrm{pH}$ data from 3 experiments that used the same observation system and were previously published in the Journal of Dairy Science were used in our investigation. The first experiment investigated the effect of fiber concentration and digestibility (Oba and Allen, 2000), the second experiment investigated the effect of starch concentration and digestibility (Oba and Allen, 2003), and the third investigated the effect of fat supplementation and supplement saturation (Harvatine and Allen, 2006).

\section{Experiment 1: Effects of Fiber on Daily Feed Intake, Rumination, and Rumen $\mathrm{pH}$}

The experiment (Oba and Allen, 2000) was conducted from late January to mid-April 1996. Briefly, 8 multiparous Holstein cows $(70 \pm 7$ DIM; mean \pm SD) from the Michigan State University Dairy Cattle Teaching and Research Center were randomly assigned to duplicated $4 \times 4$ Latin squares balanced for carryover effects in a $2 \times 2$ factorial arrangement. Treatment factors included either high $(38 \%)$ or low $(29 \%)$ dietary NDF concentration, and either brown midrib 3 (BMR) or conventional isogenic corn silage (Table 1). All diets were fed as a TMR once per day at $1200 \mathrm{~h}$ at $110 \%$ of expected intake. Cows were housed and milked in a conventional tiestall barn for the entirety of the experiment and had exposure to artificial light from 0400 to $2300 \mathrm{~h}$.

\section{Experiment 2: Effects of Starch on Daily Feed Intake, Rumination, and Rumen $\mathrm{pH}$}

The experiment (Oba and Allen, 2003) was conducted from mid-March until mid-June 1999. Eight multiparous Holstein cows $(55 \pm 15.9$ DIM) from the Michigan State University Dairy Cattle Teaching and Research Center were randomly assigned to duplicated $4 \times 4$ Latin squares balanced for carryover effects in a 2 $\times 2$ factorial arrangement. Treatment factors included high $(32 \%)$ versus low (21\%) starch concentration and either high-moisture or dry ground corn (Table 1). All diets were fed as a TMR once per day at $1400 \mathrm{~h}$ at $110 \%$ expected intake. Cows were housed and milked in tiestalls for the duration of the experiment and artificial light was present from 0400 to $2300 \mathrm{~h}$. 


\section{Experiment 3: Effect of Fatty Acid Supplements on Daily Feed Intake, Rumination, and Rumen $\mathrm{pH}$}

The experiment (Harvatine and Allen, 2006) was conducted from mid-March to mid-June 2002. Eight multiparous Holstein cows $(77 \pm 8.7$ DIM) from the Michigan State University Dairy Cattle Teaching and Research Center were randomly used in a replicated 4 $\times 4$ Latin square designed experiment in which cows were randomly assigned to treatment sequence. Treatments included a low-fat control and 1 of 3 fatty acid treatments added at $2.5 \%$ of the diet: a prilled SFA supplement (Energy Booster-100, Milk Specialties Inc., Eden Prairie, MN), a UFA supplement fed as calcium salts of fatty acids (Megalac-R, Church and Dwight Co. Inc., Ewing, NJ), and a 50:50 mixture of both supplements (Table 1). All diets were fed as a TMR once per day at $0900 \mathrm{~h}$ at $115 \%$ expected intake. Cows were housed and milked in tiestalls for the duration of the experiment with artificial light provided from 0400 to $2300 \mathrm{~h}$.

\section{Data Collection}

For all experiments, feeding behavior, chewing activity, and ruminal $\mathrm{pH}$ were monitored using an automated system described by Dado and Allen (1993). Briefly, hanging feed tubs suspended from an electronic load cell monitored feed disappearance, and chewing activity was measured with a pressure transducer attached to the nose of a conventional halter. Indwelling $\mathrm{pH}$ electrodes were placed in the ventral sac of the rumen to record ruminal $\mathrm{pH}$. Sensors transmitted feed weight, chewing activity, and ruminal $\mathrm{pH}$ to a computer dataacquisition system every $5 \mathrm{~s}$ during the sampling periods of each experiment. Calibration of $\mathrm{pH}$ probes was performed daily before feeding. Raw feed weight was smoothed by averaging over $180 \mathrm{~s}$, and the rate of feed intake was calculated at 10-min intervals (Rottman et al., 2015). Rumination was defined as chewing in the absence of feed disappearance. Rate of feed intake, rumination, and rumen $\mathrm{pH}$ were averaged over 2 -h intervals for statistical analysis. Rumen evacuations were performed before and after feeding on 2 separate days in each experiment. Briefly, rumen contents were removed, weighed, subsampled, and analyzed for nutrient composition as described in the previous corresponding publications for each experiment. Sampling occurred 2 $\mathrm{h}$ before and after feeding in experiment $1,4 \mathrm{~h}$ before and after feeding in experiment 2 , and $2 \mathrm{~h}$ before and $4.5 \mathrm{~h}$ after feeding in experiment 3 .

\section{Statistical Analysis}

Rumination, rumen $\mathrm{pH}$, and eating rate data were analyzed using the MIXED procedure of SAS 9.3 (SAS Institute Inc., Cary, NC). Experiments 1 and 2 were analyzed as a Latin square design with a $2 \times 2$ factorial arrangement of treatments. Experiment 1 included the fixed effects of NDF concentration, corn silage type, time of day, and their interactions as well as the random effects of cow and period. The model for experiment 2 included the fixed effects starch concentration, corn grain conservation method, time of day, and their interactions as well as the random effects of cow and period. The model for experiment 3 included the fixed effects of treatment, time of day, and their interaction as well as the random effects of cow and period. Least squared means for each treatment were separated using preplanned contrasts. Rumen evacuation data were analyzed in JMP Pro (SAS Institute Inc.) with a model that included the random effects of cow and period and the fixed effects of treatment, sampling time, and treatment by sampling time interaction. We found no significant treatment by sampling time interactions.

\section{Cosine Analysis}

Cosine analysis was performed according the method described by Rottman et al. (2014). Briefly, the time

Table 1. Summary of experiments and treatments

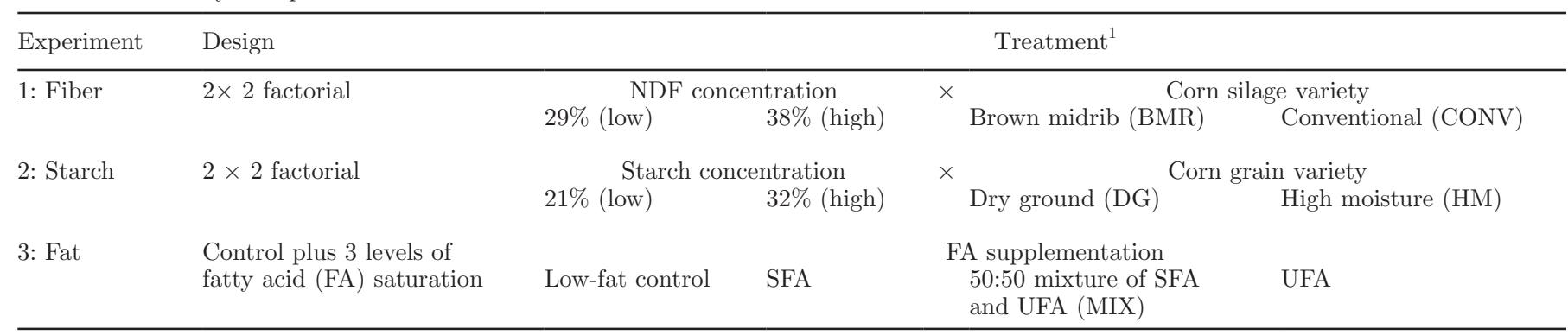

${ }^{1} \mathrm{NDF}$ and starch concentrations are expressed as a percent of diet DM. Experiment 1 was published as Oba and Allen (2000), experiment 2 was published as Oba and Allen (2003), and experiment 3 was published as Harvatine and Allen (2006). Names in parentheses denote treatment designations used in the text. 
course of rumination was fit to the linear form of the cosine function according to Bourdon et al. (1995) using random regression in SAS 9.3 (Seltman, 1997). The model tested the random effects of cow and period and the fixed effects of treatment and the interaction of treatment with the linear form of cosine functions with 24 -h periods. A 12 -h harmonic regression term was included if it improved model fit according to the Bayesian information criterion. A zero-amplitude test was conducted to determine the fit of a 24-h function for each treatment. The mean of the cosine function is reported as treatment least squares means from the linear form of the cosine function. The time at peak (acrophase) and amplitude of the rhythm, with subsequent significance tests, were calculated according to Bourdon et al. (1995).

\section{RESULTS}

\section{Effect of NDF Concentration and Digestibility}

Experiment 1 investigated the interaction of dietary NDF concentration and BMR and conventional corn silage. There was an effect of time on feed intake, rumination, and rumen $\mathrm{pH}$, with all treatments generally following a similar daily pattern $(P<0.001$; Figure $1)$. No 3-way interactions among NDF concentration, corn silage variety, and time of day were observed $(P=$ $0.78)$. However, a 2-way interaction did occur between NDF concentration and time of day for both rumination time and rumen $\mathrm{pH}(P<0.05$; Figure $1 \mathrm{C}, \mathrm{E})$. Time spent ruminating was greater for cows fed a high NDF concentration across the entire day, but the effect was larger from approximately 1600 to $2400 \mathrm{~h}(P=$ 0.02 ). Rumen $\mathrm{pH}$ was greater in the high-NDF treatment from approximately 1800 to $0600 \mathrm{~h}$. No interactions occurred between corn silage treatment and time for feed intake, rumination, or rumen $\mathrm{pH}(P>0.10$; Figure 1B, D, F).

Rumination data were fit to the linear form of a cosine function with a 24 -h period to test for modification of a daily rhythm by diet (Table 2). Cows in the high-NDF BMR, high-NDF conventional silage, and low-NDF BMR treatments exhibited 24-h rhythms $(P$ $<0.05$ ), whereas cows in the low-NDF conventional silage treatment exhibited a strong trend for a daily rhythm $(P=0.05)$. The amplitude and acrophase of the 24-h rhythm did not differ between BMR or conventional corn silage at high NDF concentrations $(P$ $>0.05$ ). When low NDF concentrations were fed, corn silage type affected the amplitude $(P<0.05)$ but not the phase $(P>0.05)$ of the daily rumination rhythm, with a $39 \%$ greater magnitude of oscillation occurring in cows fed BMR. Diet NDF concentration affected the acrophase $(P<0.05)$ but not the amplitude $(P>0.05)$ of the daily rhythm of rumination in BMR-fed cows, with peak rumination occurring $2.1 \mathrm{~h}$ later in cows fed a low-NDF diet. Both the amplitude and acrophase differed between high- and low-NDF diets in cows fed conventional corn silage $(P<0.05)$. The high-NDF diets shifted the rhythm of rumination $1.6 \mathrm{~h}$ earlier and decreased the degree of oscillation by $21 \%$ compared with the low-NDF treatment $(P<0.05)$.

\section{Effect of Starch Concentration and Digestibility}

Experiment 2 investigated the interaction of dietary starch concentration in diets containing high moisture and dry ground corn. There was an effect of time on feed intake, rumination, and rumen $\mathrm{pH}$, with all treatments generally following a similar daily pattern $(P<$ 0.001; Figure 2). No 3-way interactions between starch concentration, corn grain preservation method, or time of day were observed $(P=0.69)$. A starch concentration by time of day interaction was found for rumination behavior, with the low-starch diet decreasing rumination during the overnight and early morning $(0200 \mathrm{~h}$ to $1200)$, but not during the day $(P>0.10$; Figure $2 \mathrm{C})$. There was no starch by time of day interaction for rumen $\mathrm{pH}$, with the high-starch diet decreasing rumen $\mathrm{pH}$ throughout the day (Figure 2E). No interaction of corn grain preservation method and time of day occurred for eating rate, rumination time, or rumen $\mathrm{pH}(P>0.10)$.

A daily rhythm of rumination was observed in all treatments by cosine analysis (Table $2 ; P<0.001$ ). In both the dry ground and high-moisture corn treatments, elevating dietary starch increased the amplitude of the daily rumination rhythm $(P<0.05)$. The acrophase also differed by starch concentrations in cows fed both grain types, with high-starch diets shifting the amplitude later in the day for both $(P<0.05)$. The increase in amplitude from high-starch concentration was more pronounced in cows fed high-moisture corn, whereas a greater phase shift from low to high starch concentration occurred in cows fed dry ground corn.

\section{Effect of Fat Concentration and Saturation}

A time of day effect was observed for feed intake, rumination, and rumen $\mathrm{pH}$ in experiment 3 , which investigated the addition of a fat supplement and fat supplement saturation $(P<0.001)$. There were no 2 -way interactions of dietary fat treatment and time of day for feed intake, rumination, or rumen $\mathrm{pH}(P>$ 0.10 ; Figure 3).

A 24-h rhythm of rumination was observed for all treatments $(P<0.001 ;$ Table 2$)$. The amplitude of the daily rumination rhythm was 30 and $36 \%$ greater in 
the SFA and mixed treatments compared with control $(P<0.05)$, respectively, but no difference was observed between control and UFA $(P>0.05)$. Acrophase also differed by treatment with the peak of the daily rhythm occurring $37 \mathrm{~min}$ earlier in SFA and $42 \mathrm{~min}$ earlier in UFA than control $(P<0.05)$.

\section{Effect of Feeding on Rumen Composition}

In all 3 experiments, rumen evacuations were performed before and after feeding to determine the effects of the daily pattern of intake on rumen pool sizes and nutrient composition at expected high and low points (Table 3 ). No treatment by time interactions were detected in any of the 3 experiments $(P>$ 0.05). In experiment 1 , the rumen pool size of DM, NDF, 120-h in vitro indigestible NDF, ADF, starch, and lignin were all greater postfeeding than prefeeding $(P<0.05)$. The concentration of starch increased from 10.9 to $13.3 \%$ postfeeding, whereas the concentrations of NDF, indigestible NDF, ADF, and lignin decreased. In experiment 2 , pool size of DM, NDF, 120 -h in vitro indigestible NDF, and starch increased by 34, 20, 14, and $122 \%$ postfeeding, respectively $(P<0.05)$. Ruminal starch concentration increased from 4.7 to $8.4 \%$ after feeding, whereas NDF and iNDF decreased by

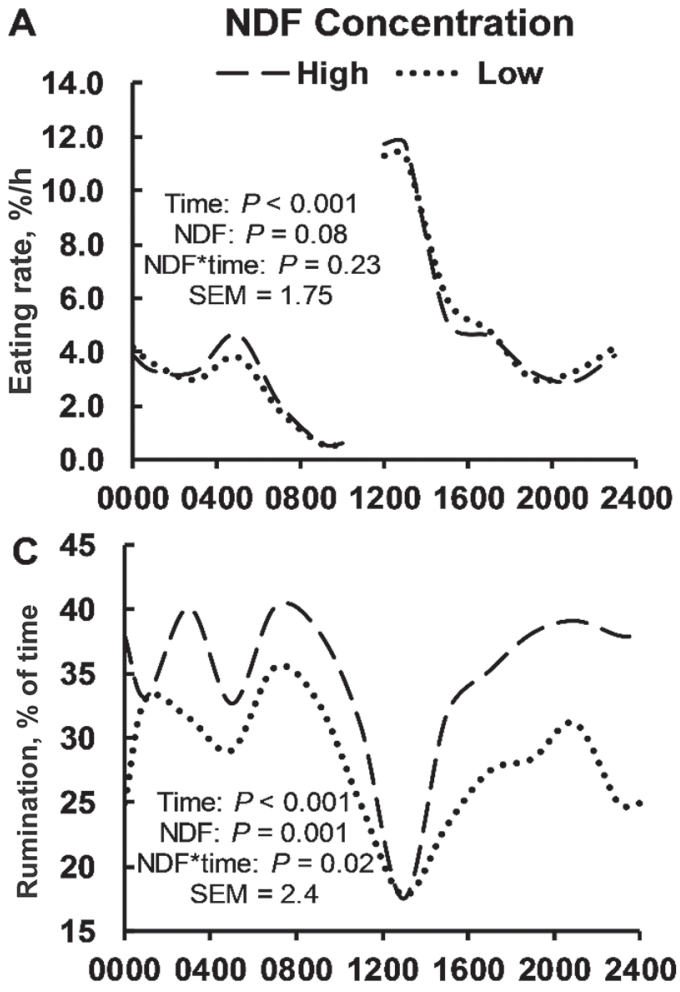

B

Corn Silage Variety
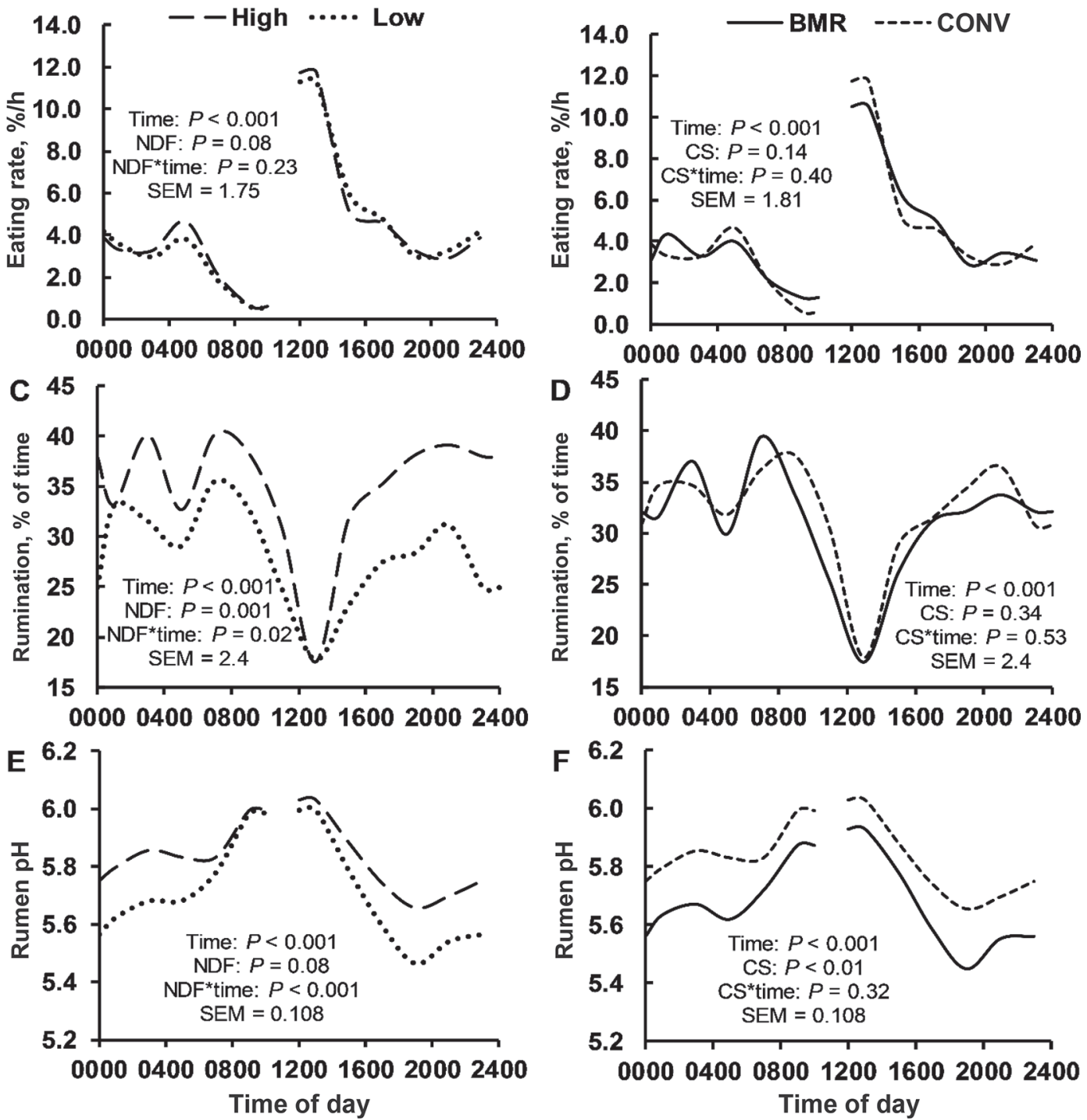

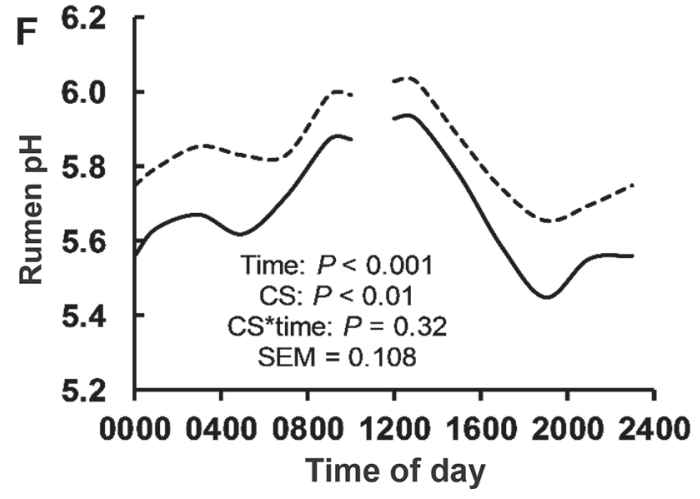

Figure 1. Effect of fiber level and digestibility (experiment 1; Oba and Allen, 2000) on feed intake (A and B), rumination (C and D), and rumen $\mathrm{pH}(\mathrm{E}$ and $\mathrm{F})$. High = High NDF concentration (38\%); Low = low NDF concentration (29\%); BMR = brown midrib corn silage; CONV $=$ conventional corn silage. The $P$-values for the main effects of time, NDF concentration (NDF), and corn silage variety (CS) and the interactions of time with NDF concentration and corn silage variety and pooled SEM are reported in each panel. Cows were fed $1 \times / \mathrm{d}$ at $1200 \mathrm{~h}$. 


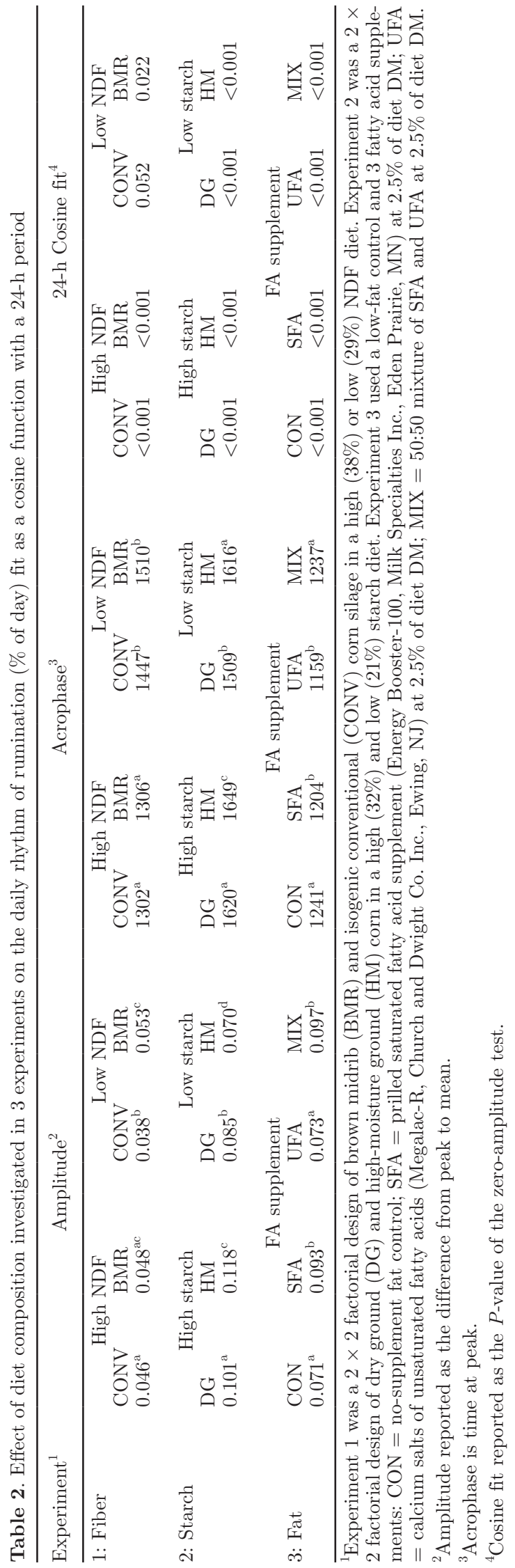

6.1 and 5.5 percentage units, respectively $(P<0.05)$. In experiment $3, \mathrm{DM}, \mathrm{NDF}, 240-\mathrm{h}$ in vitro indigestible NDF, ADF, and lignin pool sizes increased by 28, 16, 11,16 , and $9 \%$ after feeding, respectively $(P<0.05)$. Starch pool size was also greatly increased after feeding, with a $150 \%$ greater pool size postfeeding than prefeeding $(P<0.05)$. The rumen concentrations of NDF, 240-h in vitro indigestible NDF, ADF and lignin decreased after feeding, whereas the concentration of starch increased by $90 \%$.

\section{DISCUSSION}

The daily pattern of feed intake was highly consistent among treatments in all 3 experiments. Briefly, a dramatic increase in feed intake occurred immediately after feed delivery, as expected from conditioned feeding. Additionally, the majority of feed consumption occurred between dawn and dusk, in concurrence with previous research (DeVries et al., 2003; Niu et al., 2017). In the experiments investigating NDF concentration and digestibility (experiment 1) and starch concentration and digestibility (experiment 2), the rate of feed intake steadily declined after feed delivery and reached a plateau of approximately $4 \% / \mathrm{h}$ in the late afternoon. The rate of intake was more variable across the day in the experiment investigating the effect of fat level and saturation (experiment 3), with cows on all treatments consuming feed at a high rate immediately after feeding and displaying a second peak of intake around $1500 \mathrm{~h}$. It is noteworthy that cows were fed at $1200 \mathrm{~h}$ in experiment 1 , at $1400 \mathrm{~h}$ in experiment 2, and at $0900 \mathrm{~h}$ in experiment 3 . There was also more variation in feed intake overnight in experiment 3 , with the SFA, UFA, and mixed treatments exhibiting a small increase in intake at $0530 \mathrm{~h}$ compared with control, which coincided with morning milking.

The daily pattern of rumination was generally inverse of feed intake, in agreement with previous reports (Beauchemin et al., 1990; Sheahan et al., 2011; Schirmann et al., 2012). In all experiments and treatments, rumination declined immediately after feed delivery and increased as feed consumption rate declined. Nutrient composition, but not source, influenced the daily pattern of rumination in experiments 1 and 2 . In both experiments, the daily pattern of rumination was affected by the ratio of NDF to starch. HigherNDF diets caused an expected increase in rumination, but the increase compared with high-starch diets was dependent upon the time of day. In both experiments, no difference was seen among treatments at the time of feeding because of the prevention of rumination during feed consumption. In experiment 2, the largest difference in rumination between high- and low-starch 
treatments was observed during the overnight period. Fat supplements did not appear to affect the daily pattern of rumination, evidenced by no treatment effect or treatment by time interaction.

Rumination fit a 24-h rhythm in all experiments and treatments. Within experiments, the acrophase of the rumination rhythm was slightly different among treatments. In experiment 1 , low-NDF diets delayed the daily rumination rhythm so that the acrophase occurred $\sim 2 \mathrm{~h}$ later. The acrophase varied from 1509 to $1649 \mathrm{~h}$ in experiment 2, with the earliest acrophase occurring in the low-starch, dry ground corn treatment and the latest occurring in the high-starch, high-moisture corn treatment. There was also very little numerical difference in the acrophase of each treatment in experiment 3, with treatments ranging 1159 to $1237 \mathrm{~h}$. Although some statistically significant changes occurred among treatments, the differences observed are likely not biologically relevant.

The amplitude of the daily rhythm of rumination differed by treatment within each experiment. In experiment 1, decreasing NDF concentration decreased the amplitude of the daily rumination rhythm when conventional corn silage was fed, but the opposite effect was observed when diets contained BMR corn silage. In experiment 2 , high starch concentrations increased the
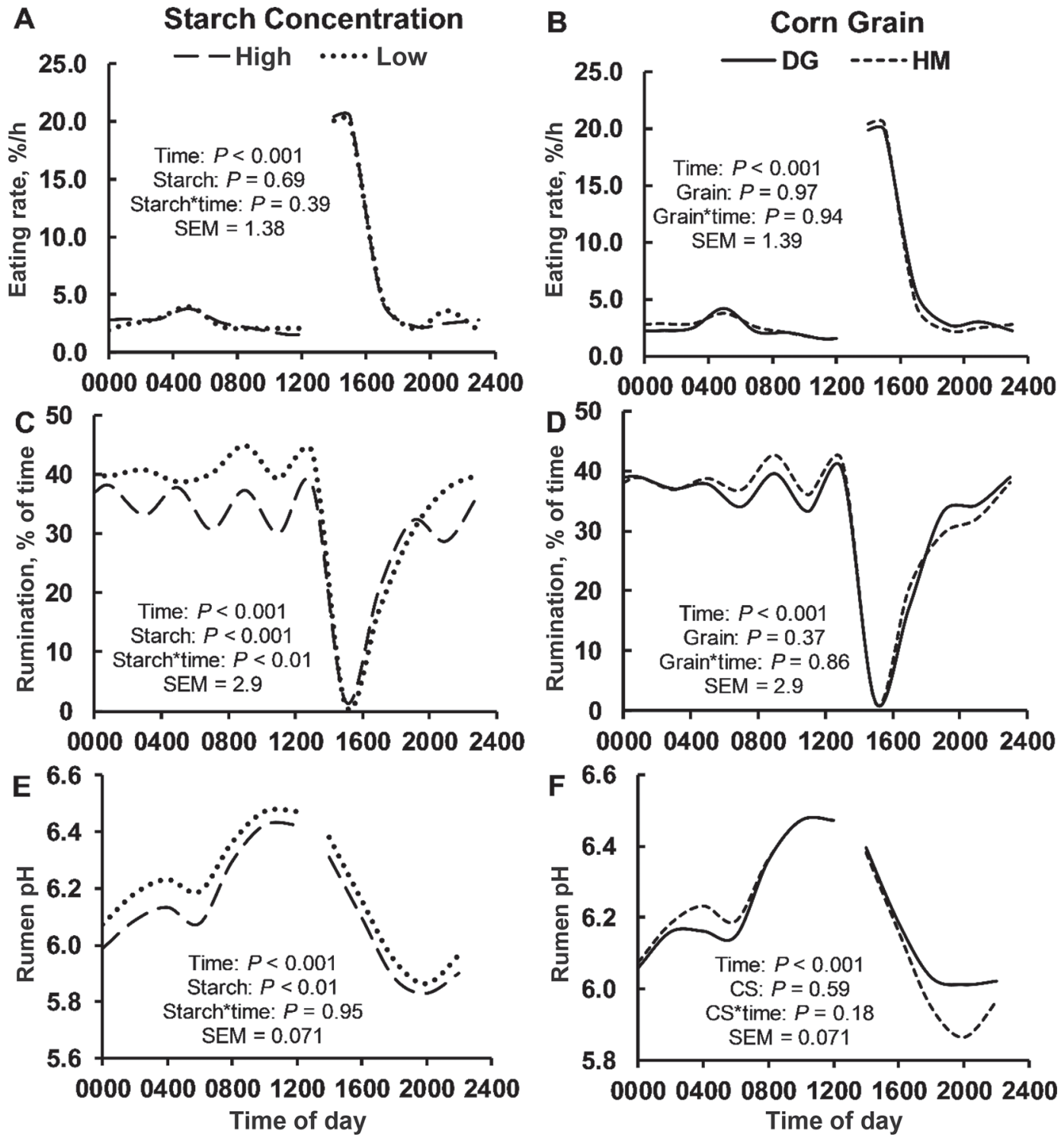

Figure 2. Effect of starch source and level (experiment 2; Oba and Allen, 2003) on feed intake (A and B), rumination (C and D), and rumen $\mathrm{pH}(\mathrm{E}$ and $\mathrm{F})$. High = high starch concentration $(32 \%)$; Low = low starch concentration $(21 \%) ; \mathrm{DG}=$ dry ground corn; and HM = high-moisture corn. The $P$-values for the main effects of time, starch concentration (Starch), and corn grain (Corn) and the interactions of time with either starch or corn grain and pooled SEM are reported in eac0h panel. Cows were fed $1 \times / \mathrm{d}$ at $1400 \mathrm{~h}$. 
A Fat Supplement
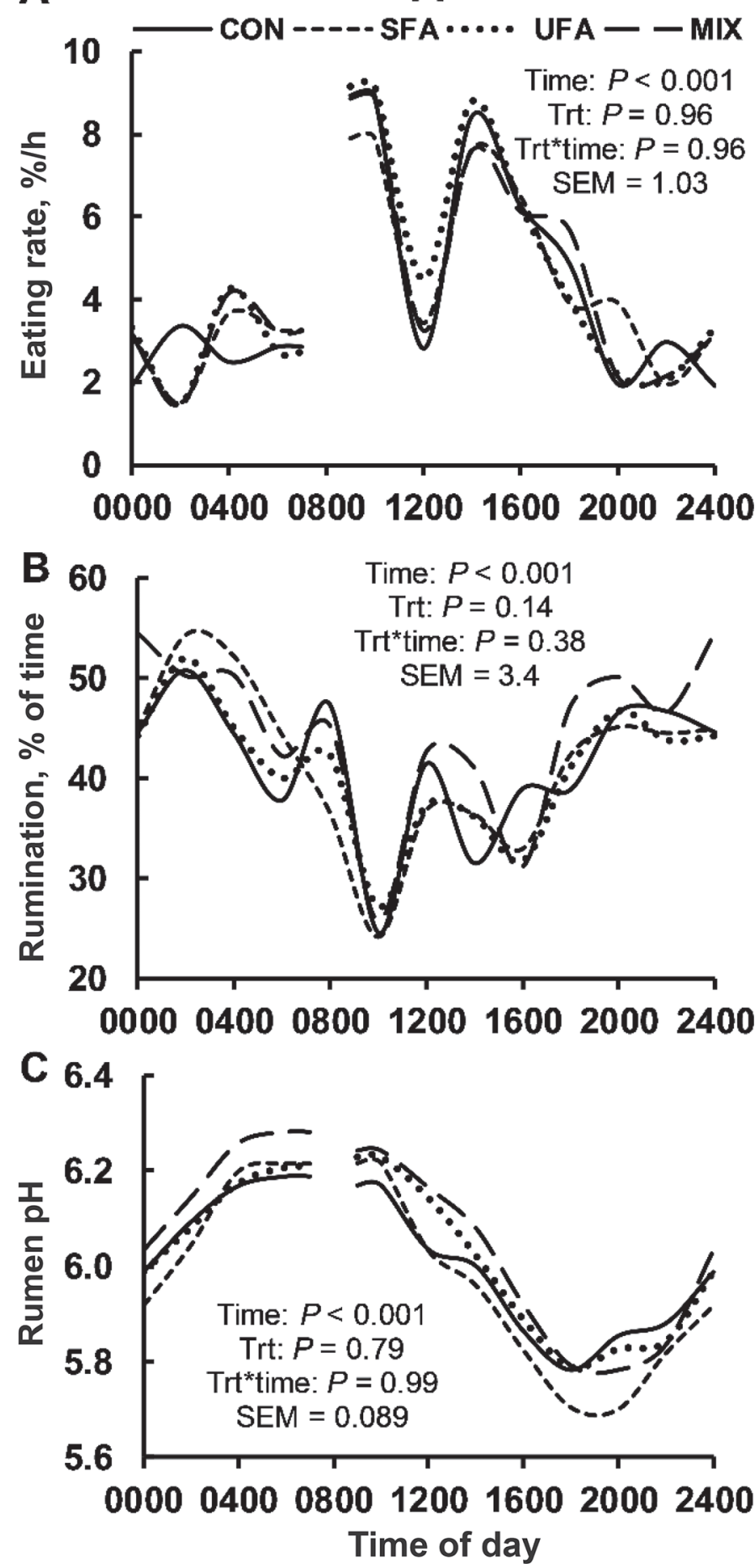

Figure 3. Effect of fat level and fatty acid profile (experiment 3 Harvatine and Allen, 2006) on feed intake (A), rumination (B), and rumen $\mathrm{pH}(\mathrm{C})$. $\mathrm{CON}=$ no-supplement control; SFA = prilled saturated fatty acid supplement (Energy Booster-100, Milk Specialties Inc., Eden Prairie, MN); UFA = calcium salts of unsaturated fatty acids (Megalac-R, Church and Dwight Co. Inc., Ewing, NJ), and MIX = 50:50 mixture of SFA and UFA. The effect of time, fatty acid supplement, and their interaction and the pooled SEM are reported in each panel. Cows were fed $1 \times / \mathrm{d}$ at $0900 \mathrm{~h}$. amplitude of daily rhythms of rumination, suggesting that although total rumination decreases with more fermentable diets, the difference between mean and peak increases. Fat supplementation also affected the amplitude of daily rumination rhythms. Supplementation with SFA or a mixture of SFA and UFA increased the amplitude of the daily rhythms. Alternatively, supplementation with UFA alone had no effect. Multiple reports have shown a 24-h rhythm of rumination (Murphy et al., 1983; Beauchemin et al., 1990; Deswysen et al., 1993). Factors including feeding time (Gordon, 1958; Welch et al., 1969) and photoperiod (Gordon and McAllister, 1970) have been reported to influence the daily rhythm of rumination. The results of the current study are in agreement with studies from Pearce (1965) and Beauchemin et al. (1990), which found no effect of physical or chemical feed characteristics on the daily pattern of rumination but observed changes in total rumination time.

A similar daily pattern of rumen $\mathrm{pH}$ occurred within all experiments and treatments. Rumen $\mathrm{pH}$ increased before feeding, and reached a maximum when feed was delivered. Furthermore, $\mathrm{pH}$ reached a nadir between 1630 and $2030 \mathrm{~h}$ in all treatments despite differences in feeding times. The only interaction between time of day and treatment occurred for NDF concentration in experiment 1 . During most of the day, rumen $\mathrm{pH}$ was greater for the high-NDF treatment, but showed no difference from the low-NDF treatment near feeding. Greater rumination occurred when conventional corn silage was fed compared with BMR. Brown midrib corn silage has lower lignin concentration and greater digestibility (Frenchick et al., 1976) and fragility (Oba and Allen, 2000) than conventional corn silage. Consistent with previous reports, the decline in rumen $\mathrm{pH}$ when BMR corn silage was fed was not associated with a decrease in rumination (Aydin et al., 1999). The results of our study indicate that this effect persists throughout the day. Whereas a higher starch concentration decreased rumen $\mathrm{pH}$ in experiment 2 , it did not affect the daily pattern of $\mathrm{pH}$. Feeding high-moisture corn versus dry ground corn did not affect rumen $\mathrm{pH}$ or its daily pattern. The ensiling process of high-moisture corn typically degrades the protein matrix surrounding the starch granules within the endosperm, resulting in greater ruminal fermentation (Hoffman et al., 2011). Cooper et al. (2002) observed an interaction between time of day and corn-processing method on rumen $\mathrm{pH}$ in beef steers. In their experiment, dry rolled corn had a greater $\mathrm{pH}$, and a more gradual daily $\mathrm{pH}$ decline compared with both high-moisture corn and steam-flaked corn. Similar to the current experiment, all treatments reached maximal rumen $\mathrm{pH}$ around $0900 \mathrm{~h}$ and were lowest in the mid-afternoon (Cooper et al., 2002). Fat 
supplementation had no effect on the daily pattern of rumen $\mathrm{pH}$. Previous reports have shown that prilled fatty acids and calcium salts of fatty acids do not affect average daily rumen pH (Grummer, 1988; Schauff and Clark, 1989). The results of the current experiment suggest that fatty acids not only fail to modify average daily rumen $\mathrm{pH}$, but they also exert no effect on its daily pattern.
Rumen pool size is a product of the rate of intake and the rates of ruminal turnover. Rumen pool size of DM, NDF, indigestible NDF, ADF, starch and lignin were consistently greater in the afternoon than morning, indicating that the high rate of intake after feeding modifies substrate available for fermentation. This agrees with Ying et al. (2015), who performed rumen evacuations 3 times over the day and observed that the

Table 3. Effect of diet composition investigated in 3 experiments on the rumen pool size before and after feeding determined by rumen evacuation

\begin{tabular}{|c|c|c|c|c|}
\hline Experiment & Prefeeding & Postfeeding & SEM & $\begin{array}{c}P \text {-value } \\
\text { Time }^{1}\end{array}$ \\
\hline \multicolumn{5}{|l|}{ 1: Fiber $^{2}$} \\
\hline \multicolumn{5}{|c|}{ Rumen pool, kg } \\
\hline $\mathrm{DM}$ & 19.9 & 25.5 & 1.5 & $<0.001$ \\
\hline NDF & 13.6 & 16.5 & 1.0 & $<0.001$ \\
\hline $\mathrm{iNDF}_{120}{ }^{3}$ & 7.9 & 8.5 & 0.6 & 0.02 \\
\hline $\mathrm{ADF}$ & 7.2 & 8.5 & 0.5 & $<0.001$ \\
\hline Starch & 2.2 & 3.4 & 0.2 & $<0.001$ \\
\hline Lignin & 1.5 & 1.7 & 0.1 & $<0.001$ \\
\hline \multicolumn{5}{|c|}{ Rumen composition, \% } \\
\hline NDF & 69.5 & 64.7 & 0.9 & $<0.001$ \\
\hline $\mathrm{iNDF}_{120}$ & 39.6 & 33.7 & 0.7 & $<0.001$ \\
\hline $\mathrm{ADF}$ & 36.5 & 33.4 & 0.4 & $<0.001$ \\
\hline Starch & 10.9 & 13.3 & 0.4 & $<0.001$ \\
\hline Lignin & 7.5 & 6.8 & 0.1 & $<0.001$ \\
\hline \multicolumn{5}{|c|}{ 2: Starch $^{4}$} \\
\hline \multicolumn{5}{|c|}{ Rumen pool, kg } \\
\hline $\mathrm{DM}$ & 17.5 & 23.4 & 1.0 & $<0.001$ \\
\hline NDF & 10.3 & 12.4 & 0.7 & $<0.001$ \\
\hline $\mathrm{iNDF}_{120}$ & 6.3 & 7.2 & 0.4 & $<0.001$ \\
\hline Starch & 0.9 & 2.0 & 0.1 & $<0.001$ \\
\hline \multicolumn{5}{|c|}{ Rumen composition, $\%$} \\
\hline NDF & 58.9 & 52.8 & 1.3 & $<0.001$ \\
\hline $\mathrm{iNDF}_{120}$ & 36.3 & 30.8 & 1.1 & $<0.001$ \\
\hline Starch & 4.7 & 8.4 & 0.3 & $<0.001$ \\
\hline \multicolumn{5}{|c|}{ 3: Fatty acids ${ }^{5}$} \\
\hline \multicolumn{5}{|c|}{ Rumen pool, kg } \\
\hline $\mathrm{DM}$ & 12.2 & 15.6 & 0.53 & $<0.001$ \\
\hline NDF & 6.8 & 7.9 & 0.25 & $<0.001$ \\
\hline $\mathrm{iNDF}_{240}{ }^{6}$ & 3.5 & 3.9 & 0.15 & 0.02 \\
\hline $\mathrm{ADF}$ & 4.5 & 5.2 & 0.17 & $<0.001$ \\
\hline Starch & 0.6 & 1.5 & 0.08 & $<0.001$ \\
\hline Lignin & 1.1 & 1.2 & 0.05 & $<0.001$ \\
\hline \multicolumn{5}{|c|}{ Rumen composition, \% } \\
\hline NDF & 57.0 & 51.2 & 0.41 & $<0.001$ \\
\hline $\mathrm{iNDF}_{240}$ & 29.6 & 25.1 & 0.82 & $<0.001$ \\
\hline $\mathrm{ADF}$ & 37.6 & 33.8 & 0.45 & $<0.001$ \\
\hline Starch & 4.8 & 9.1 & 0.37 & $<0.001$ \\
\hline Lignin & 8.9 & 7.8 & 0.23 & $<0.001$ \\
\hline
\end{tabular}

${ }^{1}$ Treatment effects have been previously published in Oba and Allen (2000) for experiment 1, Oba and Allen (2003) for experiment 2, and Harvatine and Allen (2006) for experiment 3. No treatment by time interactions occurred for any responses $(P>0.05)$.

${ }^{2} \mathrm{~A} 2 \times 2$ factorial design of brown midrib (BMR) and isogenic conventional (CONV) corn silage in a high$(38 \%)$ or low-NDF $(29 \%)$ diet. Rumen evacuations were preformed $2 \mathrm{~h}$ before and $2 \mathrm{~h}$ after feeding at $1200 \mathrm{~h}$.

${ }^{3} \mathrm{iNDF}_{120}=$ indigestible NDF, estimated as fiber remaining after $120 \mathrm{~h}$ of in vitro ruminal fermentation.

${ }^{4} \mathrm{~A} 2 \times 2$ factorial design of dry ground (DG) and high-moisture ground (HM) corn in a high- (32\%) and lowstarch $(21 \%)$ diet. Rumen evacuations were preformed $4 \mathrm{~h}$ before and $4 \mathrm{~h}$ after feeding at $1400 \mathrm{~h}$.

${ }^{5} \mathrm{CON}=$ no-supplement fat control; SFA $=$ prilled saturated fatty acid supplement (Energy Booster-100, Milk Specialties Inc., Eden Prairie, MN) at $2.5 \%$ of diet DM; UFA = calcium salts of unsaturated fatty acids (Megalac-R, Church and Dwight Co. Inc., Ewing, NJ) at 2.5\% of diet DM; MIX = 50:50 mixture of SFA and UFA at $2.5 \%$ of diet DM. Rumen evacuations were preformed $2 \mathrm{~h}$ before and $4.5 \mathrm{~h}$ after feeding at $0900 \mathrm{~h}$.

${ }^{6}$ Indigestible NDF, estimated as fiber remaining after $240 \mathrm{~h}$ of in vitro ruminal fermentation. 
rumen OM pool is lowest before morning feeding after the low-intake overnight period and increases in the afternoon after the higher-intake period of the day. The nutrient composition of the rumen also differed across the day, with decreasing concentrations of fiber and increasing concentrations of starch in the afternoon, presumably due to the faster rate of ruminal starch turnover. Ying et al. (2015) detected similar changes in rumen composition with considerable decreases in NDF concentration and increases in starch concentration after feeding. The greater OM pool size observed in the afternoon may also increase liquid passage rate and starch outflow from the rumen (Colucci et al., 1982; Robinson et al., 1987). Furthermore, Fickett and Allen (2002) observed higher amylolytic capacity of rumen fluid after feeding compared with before feeding. Sorting for concentrate feeds may also increase starch intake after feeding, but the proportion of the difference that can be attributable to sorting is limited. Rumen pool size is often averaged across the day, but the pattern of intake creates dynamics of in the substrate available for microbial that should be considered in future experiments.

\section{CONCLUSIONS}

Contrary to our hypothesis, the daily pattern of feed intake was similar, regardless of diet. Feed intake was greatest immediately after feed delivery in all diets and decreased as the day progressed. The daily pattern of rumination was affected by NDF and starch concentrations, with low-NDF, high-starch diets causing the greater reduction in rumination during the overnight period than during mid-day. A daily rhythm of rumination occurred regardless of diet, with the exception of the high-NDF BMR diets, which exhibited a tendency for a rhythm. Feeding high-starch diets increased the amplitude of the daily rumination rhythm, as did fatty acid supplements containing either prilled SFA alone or in a 50:50 mixture with calcium salts of UFA. Rumen $\mathrm{pH}$ peaked during late morning in all diets. Elevated NDF concentration altered the daily pattern of rumen $\mathrm{pH}$, causing a smaller afternoon reduction in $\mathrm{pH}$ compared with low-NDF diets. Neither the type of corn silage nor conservation method of corn affected daily patterns of rumination or rumen $\mathrm{pH}$. Overall, daily patterns of feed intake, rumination, and rumen $\mathrm{pH}$ were only modestly affected by diet, with the most notable difference being the effect of NDF and starch concentrations on the daily patterns of rumination. Dairy producers and researchers should consider the concentrations of fiber and starch in the diet when interpreting data on rumination behavior and rumen $\mathrm{pH}$ across the day, but the daily pattern of feed intake appears to be influenced minimally by the source and concentration of fiber, starch, and fatty acids. This is consistent with a robust daily pattern of feed intake under control of circadian timekeepers.

\section{ACKNOWLEDGMENTS}

The experiments investigating fiber and starch were conducted as part of the MS thesis (EXP 1) and $\mathrm{PhD}$ dissertation (EXP 2) of M. Oba (currently of University of Alberta) and we appreciate his contribution to data collection and allowing us to conduct the daily pattern analysis. We recognize the technical assistance of Kan Zhou and Chia Lin (Caroline) Wu of Penn State University. Research was supported in part by USDA Special Grant 2009-34281-20116 (PI: Harvatine), Agriculture and Food Research Initiative Competitive Grant no. 2015-67015-23358 and 2016-68008-25025 from the USDA National Institute of Food and Agriculture (PI: Harvatine), NIH Training Grant no. GM108563 (PI: Salfer), Penn State University including USDA National Institute of Food and Agriculture Federal Appropriations under Project number PEN04539 and accession number 1000803, Cargill Inc. (Wayzata, MN; PI: Allen, EXP 1), Corn Marketing Program of Michigan (Lansing; PI: Allen, EXP 2), Milk Specialties Global (Eden Prairie, MN; PI: Allen, EXP 3), and by the Michigan Agricultural Experiment Station (East Lansing).

\section{REFERENCES}

Allen, M. S. 1996. Physical constraints on voluntary intake of forages by ruminants. J. Anim. Sci. 74:3063. https://doi.org/10.2527/1996 $.74123063 x$.

Allen, M. S., B. J. Bradford, and M. Oba. 2009. Board invited review: The hepatic oxidation theory of the control of feed intake and its application to ruminants. J. Anim. Sci. 87:3317-3334. https://doi .org/10.2527/jas.2009-1779.

Antanaitis, R., V. Zilaitis, V. Juozaitiene, R. Stoskus, and M. Televicius. 2016. Changes in reticulorumen content temperature and $\mathrm{pH}$ according to time of day and yearly seasons. Pol. J. Vet. Sci. 19:771-776. https://doi.org/10.1515/pjvs-2016-0097.

Aydin, G., R. J. Grant, and J. O'Rear. 1999. Brown midrib sorghum in diets for lactating dairy cows. J. Dairy Sci. 82:2127-2135. https: //doi.org/10.3168/jds.S0022-0302(99)75456-1.

Beauchemin, K. A., R. G. Kachanoski, and G. B. Schaalje. 1990. Characterizing rumination patterns of dairy cows using spectral analysis. J. Anim. Sci. 68:3163-3170.

Beauchemin, K. A., and W. Z. Yang. 2005. Effects of physically effective fiber on intake, chewing activity, and ruminal acidosis for dairy cows fed diets based on corn silage. J. Dairy Sci. 88:21172129. https://doi.org/10.3168/jds.S0022-0302(05)72888-5.

Bourdon, L., A. Buguet, M. Cucherat, and M. W. Radomski. 1995. Use of a spreadsheet program for circadian analysis of biological/ physiological data. Aviat. Space Environ. Med. 66:787-791.

Büchel, S., and A. Sundrum. 2014. Short communication: Decrease in rumination time as an indicator of the onset of calving. J. Dairy Sci. 97:3120-3127. https://doi.org/10.3168/jds.2013-7613.

Colucci, P. E., L. E. Chase, and P. J. Van Soest. 1982. Feed intake, apparent diet digestibility, and rate of particulate passage in dairy 
cattle. J. Dairy Sci. 65:1445-1456. https://doi.org/10.3168/jds .S0022-0302(82)82367-9.

Cooper, R. J., C. T. Milton, T. J. Klopfenstein, T. L. Scott, C. B. Wilson, and R. A. Mass. 2002. Effect of corn processing on starch digestion and bacterial crude protein flow in finishing cattle. J. Anim. Sci. 80:797-804.

Dado, R. G., and M. S. Allen. 1993. Continuous computer acquisition of feed and water intakes, chewing, reticular motility, and ruminal pH of cattle. J. Dairy Sci. 76:1589-1600. https://doi.org/10.3168/ jds.S0022-0302(93)77492-5.

Deswysen, A. G., P. Dutilleul, J. P. Godfrin, and W. C. Ellis. 1993 Nycterohemeral eating and ruminating patterns in heifers fed grass or corn silage: analysis by finite Fourier transform. J. Anim. Sci. 71:2739-2747. https://doi.org/10.2527/1993.71102739X.

DeVries, T. J., M. A. G. von Keyserlingk, and K. A. Beauchemin. 2003. Short communication: Diurnal feeding pattern of lactating dairy cows. J. Dairy Sci. 86:4079-4082. https://doi.org/10.3168/ jds.S0022-0302(03)74020-X.

Fickett, F. M., and M. S. Allen. 2002. Ruminal fluid effects on in vitro digestion kinetics of corn starch. J. Dairy Sci. 85:181.

Frenchick, G. E., D. G. Johnson, J. M. Murphy, and D. E. Otterby. 1976. Brown midrib corn silage in dairy cattle rations. J. Dairy Sci. 59:2126-2129. https://doi.org/10.3168/jds.S0022-0302(76)84497 $-9$.

Gordon, J. 1958. The effect of time of feeding upon rumination. J. Agric. Sci. 6:81-83.

Gordon, J. G., and I. K. McAllister. 1970. The circadian rhythm of rumination. J. Agric. Sci. 74:291-297. https://doi.org/10.1017/ S0021859600022905.

Grummer, R. R. 1988. Influence of prilled fat and calcium salt of palm oil fatty acids on ruminal fermentation and nutrient digestibility. J. Dairy Sci. 71:117-123. https://doi.org/10.3168/jds.S0022 $-0302(88) 79532-6$.

Harvatine, K. J., and M. S. Allen. 2006. Effects of fatty acid supplements on feed intake, and feeding and chewing behavior of lactating dairy cows. J. Dairy Sci. 89:1104-1112. https://doi.org/10 .3168/jds.S0022-0302(06)72178-6.

Hoffman, P. C., N. M. Esser, R. D. Shaver, W. K. Coblentz, M. P. Scott, A. L. Bodnar, R. J. Schmidt, and R. C. Charley. 2011. Influence of ensiling time and inoculation on alteration of the starchprotein matrix in high-moisture corn. J. Dairy Sci. 94:2465-2474. https://doi.org/10.3168/jds.2010-3562.

Murphy, M. R., R. L. Baldwin, M. J. Ulyatt, and L. J. Koong. 1983 A quantitative analysis of rumination patterns. J. Anim. Sci. 56:1236-1240. https://doi.org/10.2134/jas1983.5651236x.

Nikkhah, A., C. J. Furedi, A. D. Kennedy, S. L. Scott, K. M. Wittenberg, G. H. Crow, and J. C. Plaizier. 2011. Morning vs. evening feed delivery for lactating dairy cows. Can. J. Anim. Sci. 91:113122. https://doi.org/10.4141/CJAS10012.

Niu, M., Y. Ying, P. A. Bartell, and K. J. Harvatine. 2014. The effects of feeding time on milk production, total-tract digestibility, and daily rhythms of feeding behavior and plasma metabolites and hormones in dairy cows. J. Dairy Sci. 97:7764-7776. https://doi .org $/ 10.3168 /$ jds.2014-8261.

Niu, M., Y. Ying, P. A. Bartell, and K. J. Harvatine. 2017. The effects of feeding rations that differ in fiber and fermentable starch within a day on milk production and the daily rhythm of feed intake and plasma hormones and metabolites in dairy cows. J. Dairy Sci. 100:187-198. https://doi.org/10.3168/jds.2016-11129.

Oba, M., and M. S. Allen. 2000. Effects of brown midrib 3 mutation in corn silage on productivity of dairy cows fed two concentrations of dietary neutral detergent fiber: 1 . Feeding behavior and nutrient utilization. J. Dairy Sci. 83:1333-1341. https://doi.org/10.3168/ jds.S0022-0302(00)75000-4.

Oba, M., and M. S. Allen. 2003. Effects of corn grain conservation method on feeding behavior and productivity of lactating dairy cows at two dietary starch concentrations. J. Dairy Sci. 86:174183. https://doi.org/10.3168/jds.S0022-0302(03)73598-X.

Pearce, G. 1965. Rumination in sheep. II. The circadian pattern of rumination. Aust. J. Agric. Res. 16:635. https://doi.org/10.1071/ AR9650635.

Rabiee, A. R., K. Breinhild, W. Scott, H. M. Golder, E. Block, and I. J. Lean. 2012. Effect of fat additions to diets of dairy cattle on milk production and components: a meta-analysis and metaregression. J. Dairy Sci. 95:3225-3247. https://doi.org/10.3168/ jds.2011-4895.

Reith, S., and S. Hoy. 2012. Relationship between daily rumination time and estrus of dairy cows. J. Dairy Sci. 95:6416-6420. https:/ /doi.org/10.3168/jds.2012-5316.

Robinson, P., S. Tamminga, and A. van Vuuren. 1987. Influence of declining level of feed intake and varying the proportion of starch in the concentrate on rumen ingesta quantity, composition and kinetics of ingesta turnover in dairy cows. Livest. Prod. Sci. 17:37-62. https://doi.org/10.1016/0301-6226(87)90051-0.

Rottman, L. W., Y. Ying, K. Zhou, P. a. Bartell, and K. J. Harvatine. 2015. The effects of feeding rations that differ in neutral detergent fiber and starch concentration within a day on production, feeding behavior, total-tract digestibility, and plasma metabolites and hormones in dairy cows. J. Dairy Sci. 98:4673-4684. https://doi .org/10.3168/jds.2014-8859.

Rottman, L. W., Y. Ying, K. Zhou, P. A. Bartell, and K. J. Harvatine. 2014. The daily rhythm of milk synthesis is dependent on the timing of feed intake in dairy cows. Physiol. Rep. 2. https://doi.org/ 10.14814 /phy2.12049.

Schauff, D. J., and J. H. Clark. 1989. Effects of prilled fatty acids and calcium salts of fatty acids on rumen fermentation, nutrient digestibilities, milk production, and milk composition. J. Dairy Sci. 72:917-927. https://doi.org/10.3168/jds.S0022-0302(89)79185-2.

Schirmann, K., N. Chapinal, D. M. Weary, W. Heuwieser, and M. A. G. von Keyserlingk. 2012. Rumination and its relationship to feeding and lying behavior in Holstein dairy cows. J. Dairy Sci. 95:3212-3217. https://doi.org/10.3168/jds.2011-4741.

Seltman, H. 1997. A primer on using SAS mixed models to analyze biorhythm data. Accessed Jan. 15, 2010. http://www.stat.cmu .edu/ hseltman/SASMixed/primer.pdf.

Sheahan, A. J., E. S. Kolver, and J. R. Roche. 2011. Genetic strain and diet effects on grazing behavior, pasture intake, and milk production. J. Dairy Sci. 94:3583-3591. https://doi.org/10.3168/jds 2010-4089.

Soriani, N., G. Panella, and L. Calamari. 2013. Rumination time during the summer season and its relationships with metabolic conditions and milk production. J. Dairy Sci. 96:5082-5094. https://doi .org/10.3168/jds.2013-6620.

Welch, J. G., K. S. Gibson, and A. M. Smith. 1969. Factors affecting diurnal rumination patterns. J. Dairy Sci. 52:281.

Ying, Y., L. W. Rottman, C. Crawford, P. A. Bartell, and K. J. Harvatine. 2015. The effects of feeding rations that differ in neutral detergent fiber and starch concentration within a day on rumen digesta nutrient concentration, $\mathrm{pH}$, and fermentation products in dairy cows. J. Dairy Sci. 98:4685-4697. https://doi.org/10.3168/ jds.2014-8873. 